\title{
Characterization of mucoadhesive nasal gels containing midazolam hydrochloride prepared from Linum usitatissimum L. mucilage
}

\author{
Shyamoshree Basu1,", Amal Kumar Bandyopadhyay ${ }^{2}$ \\ ${ }^{*}$ NSHM College of Pharmaceutical Technology, West Bengal University of Technology, India, \\ ${ }^{2}$ Department of Pharmaceutical Technology, Jadavpur University, Kolkata, India
}

\begin{abstract}
Nasal drug delivery systems prepared from natural materials are gaining importance in the field of pharmaceutical technology. Mucilage isolated from Linum usitatissimum L. (LUM) seeds was reported to be an effective natural mucoadhesive agent. The present study deals with a comparison of various characteristics of nasal gels containing midazolam hydrochloride $(\mathrm{HCl})$ prepared from mucoadhesive agent extracted from Linum usitatissimum L. seeds and synthetic polymers like HPMC and Carbopol 934P in terms of texture profile analysis, mucoadhesive strength, and in vivo drug absorption profiles. It was observed that gels formulated with the natural mucilage showed better results than the synthetic gels in all aspects like hardness, adhesiveness, cohesiveness and mucoadhesive strength. The absolute bioavailability of midazolam hydrochloride from the natural gel was $97.55 \%$ whereas that of synthetic gels was $57.33 \%$ and $76.81 \%$ respectively.
\end{abstract}

Uniterms: Nasal drug/delivery systems. Midazolam hydrochloride/bioavailability. Linum usitatissimum L./ pharmacognosy. Linum usitatissimum L./mucoadhesive agent. Natural mucilage/nasal gel.

\begin{abstract}
Sistemas de liberação nasal preparados com produtos naturais estão ganhando importância no campo da tecnologia farmacêutica. A mucilagem isolada de sementes de Linum usitatissimum L. (LUM) mostrouse agente mucoadesivo eficaz. O presente estudo trata da comparação de várias características de géis nasais contendo cloridrato de midazolam preparados com agente mucoadesivo extraído das sementes de Linum usitatissimum L. e com polímeros sintéticos, como HPMC e Carbopol 943P, com relação ao perfil de textura, força mucoadesiva e perfis de absorção do fármaco in vivo. Observou-se que os géis formulados com mucilagem natural apresentam melhores resultados do que os sintéticos em todos os aspectos, como dureza, adesão, coesão e força mucoadesiva. A biodisponibilidade absoluta do cloridrato de midazolam a partir do gel natural foi de $97,55 \%$, enquanto que nos géis sintéticos foi de $57,33 \% \mathrm{e}$ $76,81 \%$, respectivamente.
\end{abstract}

Unitermos: Gel nasal/sistema de liberação. Cloridrato de midazolam/biodisponibilidade. Linum usitatissimum L./farmacognosia. Linum usitatissimum L./agente mucoadesivo. Mucilagem natural/gel nasal.

\section{INTRODUCTION}

Mucoadhesive nasal gels provide a firmer platform of drug delivery to the nasal cavity than other types of nasal formulations like solutions, sprays and insufflations, since the mucoadhesive agents make a better contact with the nasal mucosa, which helps enhancing drug bioavailability. Various synthetic agents are available like HPMC,

\footnotetext{
*Correspondence: S. Basu. NSHM College of Pharmaceutical Technology, 124, B. L. Saha Road, Kolkata, 700053, India. E-mail: shyamoshree.basu@nshm.com
}

Carbopol 934P, sodium alginate and so on. Nowadays, natural mucilages are isolated from various plant parts and are used as mucoadhesive agents. It has been observed that natural materials are biocompatible and biodegradable, hence they are preferred to synthetic polymers. In our previous work, mucoadhesive nasal gels of midazolam were prepared from mucilages isolated from Linum usitatissimum L. seeds and it was observed that they gave better results than synthetic polymers in terms of viscosity and in vitro release profiles (Basu et al., 2009).

Linum usitatissimum L. mucilage is a water soluble heterogeneous polysaccharide composed of xylose, arabi- 
nose, glucose, galactose, galacturonic acid, rhamnose and fructose (Cui et al., 1994; Erskine et al., 1957; Hunt et al., 1962; Muralikrishna et al., 1987). It has good waterholding capacities, owing to its marked swelling capacity and high viscosity in aqueous solution (Basu et al., 2009). It has been reported that the presence of many oligo- and polysaccharides in many substances imparts mucoadhesive properties (Hunt et al., 1962). Since this mucilage is a rich source of polysaccharides and has remarkable swelling capacity and high viscosity, it was selected to prepare nasal gels of midazolam.

Midazolam is a fast acting benzodiazepine with a short elimination half-life (1.8 to $6.4 \mathrm{hr}$ ) (Tschirch et al., 2008). It is, therefore, a very useful drug for short minor procedures such as dental extraction. However, due to very poor bioavailability of this drug from the gastro-intestinal system $(\approx 36 \%)$, it is administered through intramuscular injection only where bioavailability is over $90 \%$ (Lahat et al., 2000; Scheepers et al., 2000; Pecking et al., 2002; Harbord et al., 2004; Mahmoudian et al., 2004; McCormick et $a l ., 2008)$. Nasal cavity is lined with a thin epithelial layer of mucosa and highly vascularized. Therefore, this route will be one of the best alternative routes of administration of this drug to intramuscular injection which is one of the most hazardous routes of drug administration as well as one of the most difficult to manufacture due to stringent its rules and regulations.

Hence, an attempt was made to prepare mucoadhesive nasal gels of midazolam, which may replace the conventional midazolam injection and widen the scope of novel drug delivery system.

The present study focuses on the preparation of mucoadhesive nasal gels containing midazolam hydrochloride $(\mathrm{HCl})$ and on a comparison of texture profile analyses, mucoadhesive strengths and in vivo drug absorption profiles from nasal gels prepared with mucilage isolated from Linum usitatissimum L. seeds and synthetic polymers like HPMC and Carbopol 934P.

\section{MATERIAL AND METHODS}

Midazolam hydrochloride was obtained as a gift from Sun Pharmaceutical Industries Ltd., Gujarat, India. Linum usitatissimum $\mathrm{L}$. seeds were purchased from the local market. HPMC, Carbopol 934P and sodium taurocholate were purchased from Loba Chemie Pvt. Ltd., Mumbai, India. All other reagents and chemicals used were of analytical grade.

\section{Preparation of nasal gel containing midazolam}

Mucoadhesive nasal gels were prepared by dissolving midazolam hydrochloride in nasal solution that consists of $0.65 \% \mathrm{NaCl}, 0.04 \% \mathrm{KH}_{2} \mathrm{PO}_{4}, 0.09 \% \mathrm{~K}_{2} \mathrm{HPO}_{4}$ and $0.02 \%$ benzalkonium chloride ( $\mathrm{pH} 6$ ), in a constant stirring condition. Required amounts of LUM and synthetic polymers (HPMC and Carbopol 934P) and penetration enhancer like sodium taurocholate $(0.5 \% \mathrm{w} / \mathrm{v})$ were added to the solution and stirred on a magnetic stirrer until a uniform solution was obtained. This homogenous solution was kept at $4{ }^{\circ} \mathrm{C}$ overnight to allow complete swelling so that a homogenous gel was formed. The composition of nasal gels used in the present study is provided in Table I.

\section{Characterisation of gels}

\section{Determination of texture profile analysis}

Texture profile analyses of the gels were evaluated using QTS-25 Texture Analyser (Brookfield Engineering Labs., USA) to determine the mechanical parameters like hardness, cohesiveness and adhesiveness. An analytical probe of $1.2 \mathrm{~cm}$ in diameter was depressed twice into

TABLE I - Composition of nasal gels along with formulation codes

\begin{tabular}{|c|c|c|c|c|c|}
\hline $\begin{array}{l}\text { Formulation } \\
\text { code }\end{array}$ & $\begin{array}{c}\text { Midazolam HCl } \\
(\% \mathrm{w} / \mathrm{v})\end{array}$ & $\begin{array}{l}\text { LUM } \\
(\% \mathrm{w} / \mathrm{v})\end{array}$ & $\begin{array}{l}\text { HPMC } \\
(\% \text { w/v) }\end{array}$ & $\begin{array}{c}\text { Carbopol 934P } \\
(\% \mathrm{w} / \mathrm{v})\end{array}$ & $\begin{array}{c}\text { Sodium taurocholate } \\
(\% \mathrm{w} / \mathrm{v})\end{array}$ \\
\hline$\overline{\mathrm{F} 1}$ & 5.0 & 3.0 & - & - & 0.5 \\
\hline $\mathrm{F} 2$ & 5.0 & 4.0 & - & - & 0.5 \\
\hline F3 & 5.0 & 5.0 & - & - & 0.5 \\
\hline F4 & 5.0 & - & 3.0 & - & 0.5 \\
\hline F5 & 5.0 & - & 4.0 & - & 0.5 \\
\hline F6 & 5.0 & - & 5.0 & - & 0.5 \\
\hline F7 & 5.0 & - & - & 3.0 & 0.5 \\
\hline F8 & 5.0 & - & - & 4.0 & 0.5 \\
\hline F9 & 5.0 & - & - & 5.0 & 0.5 \\
\hline
\end{tabular}


each sample to a fixed depth $(15 \mathrm{~mm})$, at a defined rate $(30 \mathrm{~mm} / \mathrm{min})$, with a defined recovery period $(15 \mathrm{~s})$, between the end of the first compression and the beginning of the second. A trigger force of $4 \mathrm{~g}$ was applied. At least six replicate analyses of each sample were performed at $37 \pm 1^{\circ} \mathrm{C}$. Data collection and evaluation were done by Texture pro software, version 2.1 (Cevher et al., 2008; Basu et al., 2010).

\section{Evaluation of mucoadhesive strength}

Mucoadhesive strengths of the gels were determined by measuring the force required to detach nasal mucous membrane from the gel using the same texture analyser. Freshly excised goat nasal membrane was attached to the upper probe of the instrument, and the fixed amount of gel was kept below that. The upper probe was then lowered at a speed of $10 \mathrm{~mm} / \mathrm{min}$ to touch the surface of the gel. A force of 0.1 Newton was applied for $5 \mathrm{~min}$ to ensure intimate contact between the membrane and the gel. The surface area of exposed mucous membrane was $1.13 \mathrm{~cm}^{2}$.

\section{Calibration curve of midazolam in rabbit plasma}

Stock solutions of midazolam were prepared in a mixture of $10 \mathrm{mM}$ phosphate buffer ( $\mathrm{pH}$ 6.0): acetonitrile $(80: 20)$ to give final concentrations of $1 \mathrm{mg} / \mathrm{mL}$. Plasma standards for calibration curves were prepared by spiking $1.0 \mathrm{~mL}$ aliquots of pooled drug free plasma with $100 \mu \mathrm{L}$ of the above mentioned working solutions, to make midazolam plasma standards ranging from 10 to $1000 \mathrm{ng} / \mathrm{mL}$.

\section{In vivo drug absorption study}

\section{Selection of animals}

The In vivo drug absorption study was conducted with prior approval of the Institutional Animal Ethics Committee and it was conducted according to the institutional guidelines of Animal Ethics Committee of Dr. B. C. Roy College of Pharmacy and Allied Health Sciences, West Bengal University of Technology, as recognized by the Committee for the Purpose of Control and Supervision on Experiments on Animals, India.

In vivo studies were conducted on $12 \mathrm{New}$ Zealand albino male rabbits weighing between 2 and $2.5 \mathrm{~kg}$. Based on results of texture profile analyses, mucoadhesive strengths and in vitro drug release pattern (Basu et al., 2009), nasal gels containing 3\% w/v LUM, $5 \% \mathrm{w} / \mathrm{v}$ Carbopol $934 \mathrm{P}$ and $5 \% \mathrm{w} / \mathrm{v}$ HPMC along with $0.5 \%$ sodium taurocholate were selected for in vivo study. The animals were kept in individual metal cages and maintained at $25^{\circ} \mathrm{C}$ for 10 days prior to the experiment. They were provided with standard diet and water ad libitum.
The rabbits were kept in fasting condition for $24 \mathrm{~h}$ before the experiment commenced. The rabbits were grouped into four (group I, II, III and IV), each group containing three rabbits. Group I was administered intravenous bolus injection of midazolam. Groups II, III and IV were administered nasal gels of midazolam prepared with LUM, Carbopol 934P and HPMC. A single dose of midazolam ( $2 \mathrm{mg} / \mathrm{kg}$ body weight of rabbit) was administrated intravenously to compare the pharmacokinetic parameters. No anesthesia was used for the intravenous study. Midazolam was injected through cannulated marginal ear vein. After every $20 \mathrm{~min}$, each rabbit was administered one-third of the initial dose of xylazine and ketamine intramuscularly to maintain a light plane of anesthesia. In case of nasal gels, the dose of midazolam administered was also $2 \mathrm{mg} /$ $\mathrm{kg}$ rabbit body weight.

\section{Collection of blood samples}

Two milliliters of blood samples were collected before intravenous injection and then at 5-, 10-, 15-, 20-, 30-, 45-, 60-, 90-, 120-, 180-, 240- and 300-min intervals in eppendorffs containing heparin sodium $(100 \mathrm{U} / \mathrm{mL})$. Immediately after each blood sample collection, the catheter was flushed with $0.2 \mathrm{~mL}$ of a $10 \%(\mathrm{v} / \mathrm{v})$ heparin/normal saline solution to prevent blood clotting inside the catheter. The blood samples were kept on ice and centrifuged at 3,000 rpm for 10 min immediately after collection to separate the plasma and stored at $-20^{\circ} \mathrm{C}$ until the time of analysis.

\section{HPLC analysis}

Reverse phase HPLC was used to quantitate midazolam in plasma samples. Midazolam was extracted with $3 \mathrm{~mL}$ of cyclohexane/diethyl ether (3:7) after the addition of $10 \mu \mathrm{L}$ of $2 \%$ sodium hydroxide (Shih et al., 2002). The organic phase was removed and evaporated to dryness under nitrogen, and the residue was reconstituted in $200 \mu \mathrm{L}$ of the mobile phase (10 mM phosphate buffer $(\mathrm{pH}$ 6.0)/acetonitrile, 80:20). From the mixture, $100 \mu \mathrm{L}$ was injected for chromatographic analysis. The mobile phase consisted of phosphate buffer/acetonitrile (80:20) v/v. The mobile phase was delivered into the HPLC apparatus at a flow rate of $1 \mathrm{~mL} / \mathrm{min}$ (isocratic pump, Model LC-10AS, Jasco, Japan). The detection wavelength was $218 \mathrm{~nm}$ (ultraviolet variable wavelength detector, Model SPD-10A), and a C18 column was used. All assays were performed at ambient temperature.

\section{Pharmacokinetic analysis}

Pharmacokinetic parameters like peak plasma concentration $\left(\mathrm{C}_{\max }\right)$, time to reach peak plasma concentration $\left(\mathrm{t}_{\max }\right)$, area under the (concentration-time) curve (AUC), 
mean residence time (MRT), elimination half-life $\left(\mathrm{t}_{1 / 2}\right)$ and total body clearance (CL) were calculated following non-compartment model by Kinetica 4.4, PK/PD Analysis, Thermoelectron Corporation. All the parameters were calculated for i.v. bolus injection of midazolam and in situ nasal gels. Fraction of dose absorbed (F) was calculated by the following equation:

$$
F=\frac{\operatorname{AUC}_{(\text {nasal }) X} \operatorname{Dose}_{(\text {iv) }}}{\operatorname{AUC}_{(\text {i.v. })} x \operatorname{Dose}_{(\text {nasal })}}
$$

where Dose $e_{(\mathrm{iv})}=$ dose of midazolam given as i.v. solution, Dose $_{(\text {nasal) }}=$ dose of midazolam in nasal gels, $\mathrm{AUC}_{(\mathrm{i} . \mathrm{v} .)}=\mathrm{AUC}$ after i.v. administration of midazolam and $\mathrm{AUC}_{(\text {nasal) }}=\mathrm{AUC}$ after nasal administration of midazolam.

\section{STATISTICS}

Data were analyzed by one-way ANOVA followed by Tukey's HSD test using Vassar stat software (USA). $\mathrm{p}<0.01$ has been considered to be significant statistically.

\section{RESULTS}

The present study determines the various mechanical properties as well as mucoadhesive strengths of the gels with the help ofQTS - 25 Texture Analyser. Results of the texture profile analysis and mucoadhesive strengths are tabulated in Table II. Hardness of LUM gels ranges from $28.00 \pm 1.11 \mathrm{~g}$ to $55.00 \pm 0.38 \mathrm{~g}$. In case of HPMC gels, it ranges from $11.00 \pm 0.50 \mathrm{~g}$ to $18.00 \pm 0.36 \mathrm{~g}$ and for Carbopol 934P it varies from $15.00 \pm 0.51 \mathrm{~g}$ to $27.05 \pm 0.32 \mathrm{~g}$. Values of adhesiveness of LUM, HPMC and Carbopol 934P gels varies from $-89.00 \pm 7.12 \mathrm{~g}$ to $-112.08 \pm 5.89 \mathrm{~g}$, $-30.60 \pm 3.03 \mathrm{~g}$ to $-51.26 \pm 6.45 \mathrm{~g}$ and $-45.03 \pm 5.02 \mathrm{~g}$ to $-80.36 \pm 7.98 \mathrm{~g}$, respectively. In a texture profile analysis graph, the curves of adhesiveness are obtained in the negative $\mathrm{X}$-axis and hence, the values are negative. Cohesiveness of LUM gels ranges from $1.01 \pm 0.05$ to $0.97 \pm 0.03$. For HPMC gels, it varies from $1.15 \pm 0.01$ to $1.00 \pm 0.03$ and for Carbopol 934P gels, it varies from $1.10 \pm 0.05$ to $0.96 \pm 0.03$.

Values of mucoadhesive strengths of the gels are also displayed in Table II, which shows that with an increase in concentration of the gels from 3\% to $5 \%$, mucoadhesive strengths of LUM gels varies from $16.26 \pm 0.98 \mathrm{~g}$ to $22.45 \pm 1.02$ g. For HPMC gels and Carbopol 934P gels, it ranges from $8.00 \pm 0.85 \mathrm{~g}$ to $11.95 \pm 0.56 \mathrm{~g}$ and from $9.63 \pm 1.02 \mathrm{~g}$ to $16.39 \pm 0.89 \mathrm{~g}$ respectively.

The calibration curve of midazolam hydrochloride prepared in rabbit plasma was found to be linear over the concentration range of $10-1,000 \mathrm{ng} / \mathrm{mL}\left(\mathrm{r}^{2}=0.9999\right)$. The experiment was repeated six times a day and for six consecutive days. Interday and intraday accuracy and precision values are displayed in Table III.

Plasma concentration-time profiles of midazolam

TABLE II - Values of texture profile analysis and mucoadhesive strength of conventional gels. Data represent mean $\pm \mathrm{SD}(\mathrm{n}=6)$

\begin{tabular}{lcccc}
\hline Formulation code & Hardness $(\mathrm{g})$ & Adhesiveness $(\mathrm{gs}$ & Cohesiveness & Mucoadhesive strength $(\mathrm{g})$ \\
\hline F1 & $28.00 \pm 1.11$ & $-89.00 \pm 7.12$ & $1.01 \pm 0.05$ & $16.26 \pm 0.98$ \\
F2 & $38.33 \pm 0.69$ & $-95.00 \pm 2.65$ & $0.99 \pm 0.02$ & $19.76 \pm 0.85$ \\
F3 & $55.00 \pm 0.38$ & $-112.08 \pm 5.89$ & $0.97 \pm 0.03$ & $22.45 \pm 1.02$ \\
F4 & $11.00 \pm 0.50$ & $-30.60 \pm 3.03$ & $1.15 \pm 0.01$ & $8.00 \pm 0.85$ \\
F5 & $14.00 \pm 0.48$ & $-40.62 \pm 4.88$ & $1.02 \pm 0.05$ & $9.50 \pm 0.36$ \\
F6 & $18.00 \pm 0.36$ & $-51.26 \pm 6.45$ & $1.00 \pm 0.03$ & $11.95 \pm 0.56$ \\
F7 & $15.00 \pm 0.51$ & $-45.03 \pm 5.02$ & $1.10 \pm 0.05$ & $9.63 \pm 1.02$ \\
F8 & $21.00 \pm 0.36$ & $-69.36 \pm 8.56$ & $1.06 \pm 0.04$ & $13.22 \pm 1.05$ \\
F9 & $27.05 \pm 0.32$ & $-80.36 \pm 7.98$ & $0.96 \pm 0.03$ & $16.39 \pm 0.89$ \\
\hline
\end{tabular}

TABLE III - Interday and intraday accuracy and precision data for quantitation of midazolam in rabbit plasma

\begin{tabular}{lcccccc}
\hline \multirow{2}{*}{$\begin{array}{l}\text { Amount of drug } \\
\text { added }(\mathrm{ng} / \mathrm{mL})\end{array}$} & \multicolumn{2}{c}{ Concentration in plasma $(\mathrm{ng} / \mathrm{mL})$} & \multicolumn{2}{c}{ Accuracy } & \multicolumn{2}{c}{ Precision $(\% \mathrm{RSD})$} \\
\cline { 2 - 6 } & \multicolumn{1}{c}{ Intraday } & Interday & Intraday & Interday & Intraday & Interday \\
\hline 10 & $9.91 \pm 0.24$ & $9.55 \pm 0.38$ & 99.10 & 95.50 & 2.42 & 3.97 \\
200 & $199.05 \pm 2.15$ & $195.99 \pm 4.51$ & 99.53 & 98.46 & 1.08 & 2.30 \\
600 & $599.30 \pm 2.65$ & $596.08 \pm 3.58$ & 99.88 & 99.34 & 0.44 & 1.10 \\
1000 & $998.05 \pm 3.95$ & $994.09 \pm 5.01$ & 99.80 & 99.41 & 0.39 & 0.50 \\
\hline
\end{tabular}


TABLE IV - Comparative pharmacokinetic parameters of midazolam hydrochloride following administration of intravenous and nasal gels in rabbits $($ dose $=2 \mathrm{mg} / \mathrm{kg})$

\begin{tabular}{lcccc}
\hline $\begin{array}{l}\text { Pharmacokinetic } \\
\text { parameters }\end{array}$ & Intravenous solution & HPMC & CP & LUM \\
\hline $\mathrm{C}_{\max }(\mathrm{ng} / \mathrm{mL})$ & $573.64 \pm 5.23$ & $151.47 \pm 7.22$ & $164.07 \pm 6.85$ & $181.12 \pm 6.21$ \\
$\mathrm{~T}_{\text {max }}(\mathrm{min})$ & - & $60.00 \pm 5.68$ & $45.00 \pm 3.66$ & $30.00 \pm 4.75$ \\
$\mathrm{AUC}_{\text {last }}$ & $32671.50 \pm 90.56$ & $18034.30 \pm 101.45$ & $22074.10 \pm 96.72$ & $26168.80 \pm 123.67$ \\
$\mathrm{AUC}_{\text {extra }}$ & $865.87 \pm 37.25$ & $1191.83 \pm 45.26$ & $3684.71 \pm 60.58$ & $5546.92 \pm 48.76$ \\
$\mathrm{AUC}_{\text {total }}$ & $33537.40 \pm 101.25$ & $19226.10 \pm 97.25$ & $25758.90 \pm 95.46$ & $31715.72 \pm 98.77$ \\
$\mathrm{MRT}_{(\min )}$ & $71.61 \pm 5.05$ & $130.16 \pm 6.58$ & $162.50 \pm 7.25$ & $190.07 \pm 8.05$ \\
$\mathrm{~T}_{1 / 2}(\min )$ & $58.78 \pm 6.32$ & $68.44 \pm 5.28$ & $99.68 \pm 4.89$ & $122.55 \pm 5.87$ \\
$\left.\mathrm{Clearence} \mathrm{X} \mathrm{10-5}_{(\mathrm{mg} / \mathrm{Kg}}^{*} \mathrm{~min} /(\mathrm{ng} / \mathrm{mL})\right)$ & $5.79 \pm 6.95$ & $10.11 \pm 3.66$ & $7.53 \pm 2.89$ & $6.67 \pm 4.22$ \\
\hline
\end{tabular}

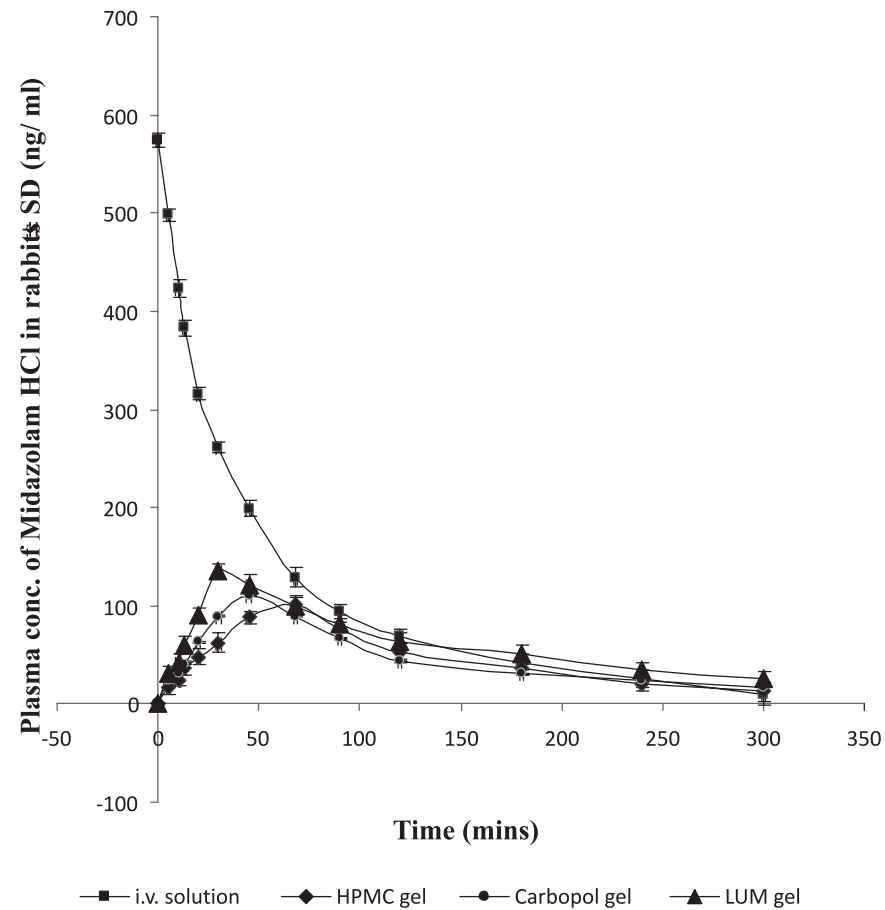

FIGURE 1 - Plasma concentration-time profiles of midazolam hydrochloride after administration of intravenous solution and the nasal gels in rabbits. Data represent mean $\pm \mathrm{SD}(\mathrm{n}=3)$.

after administration of i.v. solution and the nasal gels are shown in Figure 1. Pharmacokinetic parameters were displayed in Table IV. $\mathrm{C}_{\max }$ values of i.v. injection, LUM, HPMC and Carbopol 934P gels were $573.64 \pm 5.23$, $181.12 \pm 6.21,157.47 \pm 7.22$ and $164.07 \pm 6.85 \mathrm{ng} / \mathrm{mL}$, respectively. $\mathrm{T}_{\max }$ values of i.v. injection, LUM, HPMC and $\mathrm{CP}$ gels were $0.00,30.00 \pm 9.76,60.00 \pm 6.25$ and $45.00 \pm 7.88 \mathrm{~min}$, respectively. $\mathrm{T}_{1 / 2}$ values of i.v. injection, LUM, HPMC and CP gels were $58.78 \pm 6.32$,
$122.55 \pm 5.87,68.44 \pm 5.28$ and $99.68 \pm 4.89 \mathrm{~min}$, respectively.

\section{DISCUSSION}

The hardness of a gel determines the drug release pattern from the gel. From the results it can be said that gel containing 3\% LUM showed optimum hardness. Adhesiveness determines proper gel contact and retention at the site of application, thereby leading to enhanced bioavailability of the drug. In the present study, the adhesiveness of gels was enhanced significantly with the increase in amount of mucoadhesive agent. Cohesiveness was observed to be reduced with the increase in amount of mucoadhesive agents. This happens because with an increase in amount of dispersed solids, that are the mucoadhesive agents, the semisolid nature of the gels increased, which caused the gel to become less coherent (Cevher et al., 2008).

Mucoadhesive strength of LUM gels was found to be higher than those prepared with synthetic mucoadhesive polymers and it increased with corresponding increase in concentration of mucoadhesive agent used. This may be due to the presence of certain functional groups in the mucilage, which were able to establish a more intimate contact with mucin of the mucosa (Basu et al., 2009).

In our previous work it was shown that sodium taurocholate produced better drug release profiles than sodium thioglycollate, and the histopathological study confirmed that LUM can be used safely as a mucoadhesive agent (Basu et al., 2009). Hence, for the in vivo study, nasal gels containing $0.5 \% \mathrm{w} / \mathrm{v}$ sodium taurocholate were administered to the rabbits. Higher plasma concentration 
of midazolam hydrochloride is observed in case of LUM gels in comparison to HPMC and Carbopol 934P gels (Figure 1), and accordingly, absolute bioavailabilities of midazolam from LUM, HPMC and Carbopol gels were reported to be $97.55 \%, 57.33 \%$ and $76.81 \%$, respectively. From the in vivo study we can conclude that bioavailability of midazolam from nasal gels prepared from LUM was better than those prepared from synthetic polymers. This confirms that LUM can be effectively used as a mucoadhesive agent instead of synthetic polymers for delivery of midazolam via nasal route.

\section{CONCLUSION}

From the above study, it is confirmed that mucoadhesive nasal gels of midazolam hydrochloride prepared with mucilage isolated from Linum usitatissimum L. seeds exhibited better mechanical properties as well as in vivo drug absorption pattern. Also, bioavailability of midazolam was higher from the gels prepared with this natural mucilage than from synthetic gels. Hence, this new dosage form of midazolam prepared with a natural mucilage is a safe and cost-effective form of nasal drug delivery system.

\section{REFERENCES}

BASU, S.; CHAKRABATORTY, S.; BANDYOPADHYAY, A.K. Development and evaluation of a mucoadhesive nasal gel of midazolam prepared with Linum usitatissimum $\mathrm{L}$. seed mucilage. Sci. Pharm., v.77, p.899-910, 2009.

BASU, S.; BANDYOPADHYAY, A.K. Development and Characterization of Mucoadhesive In Situ Nasal Gel of Midazolam Prepared with Ficus carica Mucilage. AAPS Pharm Sci Tech., v.11, p.1224-1231, 2010.

CEVHER, E.; TAHA, M.A.M.; ORLU, M.; ARAMAN, A. Evaluation of mechanical and mucoadhesive properties of clomiphene citrate gel formulations containing carbomers and their thiolated derivatives. Drug Dev., v.15, p.57-67, 2008 .

CUI, W.; MAZZA, G.; BILIADERISS, C.G. Chemical structure, molecular size distributions, and rheological properties of flaxseed gum. J. Agric. Food Chem., v.42, p.1891-1895, 1994.

ERSKINE, A.J.; JONES, J.K.N. The structure of linseed mucilage (Part I). Can. J. Chem., v.35, p.1174-1182, 1957.
FEDENIUK, R.K.; BILIADERIS, C.G. Composition and physicochemical properties of linseed mucilage. J. Agric. Food Chem., v.42, p.240-247, 1994.

GOLDMAN, R.D. Intranasal drug delivery for children with acute illness. Curr. Drug Ther., v.1, p.127-130, 2006.

HARDING, S.E. Mucoadhesive interactions. Biochem. Soc. Trans., v.31, p.1036-1041, 2003.

HUNT, K.; JONES, J.K.N. The structure of linseed mucilage. Can. J. Chem., v.40, p.1266-1279, 1962.

HARBORD, M.G.; KYRKOU, N.E.; KYRKOU, M.R.; KAY, D.; COULTHARD, K.P. Use of intranasal midazolam to treat acute seizures in paediatric community settings. $J$. Paediatr. Child H., v. 40, p.556-558, 2004.

LAHAT, E.; GOLDMAN, M.; BARR, J.; BISTRITZER, T.; BERKOVITCH, M. Comparison of intranasal midazolam with intravenous diazepam for treating febrile seizures in children: prospective randomised study. BMJ (Clin. Res. Ed.), v.321, p.83-86, 2000.

MAHMOUDIAN, T.; ZADEH, M.M. Comparison of intranasal midazolam with intravenous diazepam for treating acute seizures in children. Epilepsy Behav., v.5, p.253-255, 2004.

MCCORMICK, A.S.; THOMAS, V.L.; BERRY, D.; THOMAS, P.W. Plasma concentrations and sedation scores after nebulized and intranasal midazolam in healthy volunteers. Br. J. Anaesth., v.100, p.631-636, 2008.

MURALIKRISHNA, G.; SALIMATH, P.V.; THARANATHAN, R.N. Structural features of an arabinoxylan and a rhamnogalacturonan derived from linseed mucilage. Carbohydr. Res., v.161, p.265-271, 1987.

PECKING, M.; MONTESTRUC, F.; MARQUET, P.; WODEY, E.; HOMERY, M.C.; DOSTERT, P. Absolute bioavailability of midazolam after subcutaneous administration to healthy volunteers. Br. J. Clin. Pharmacol., v.54, p.357-362, 2002.

SHIH, P.E.; HUANG, J.D. Pharmacokinetics of midazolam and 1-hydroxymidazolam in Chinese with different cyp3a5 genotypes. Drug Metab. Dispos., v.30, p.1491-1496, 2002. 
SCHEEPERS, M.; SCHEEPERS, B.; CLARKE, M.; COMISH, S.; IBITOYE, M. Is intranasal midazolam an effective rescue medication in adolescents and adults with severe epilepsy? Seizure, v.9, p. 417-422, 2000.
TSCHIRCH, F.T.C; SUTER, K; FROEHLICH, J.M.; STUDLER, U.; NIDECKER, A.; ECKHARDT, B.; BERANEK-CHIU, J.; SURBER, C.; WEISHAUPT, D. Multicenter trial: comparison of two different formulations and application systems of low-dose nasal midazolam for routine magnetic resonance imaging of claustrophobic patients. J. Magn. Reson. Im., v.28, p.866-872, 2008.

Received for publication on $06^{\text {th }}$ May 2011 Accepted for publication on $31^{\text {st }}$ August 2011 
